\title{
An exploration of residents' intended wildfire evacuation responses in Mt. Lorne, Yukon, Canada
}

\author{
by Doug W. Cote ${ }^{1}$ and Tara K. McGee ${ }^{2}$
}

\begin{abstract}
Wildfire evacuations disrupt people's lives, create an additional hazard for emergency responders and residents, and are expensive to execute. Alternatives to evacuation are used in Australia and a few jurisdictions in the United States. Numerous studies have examined the "stay and defend" option during a wildfire in Australia, and evacuation alternatives have also been examined in the US. However, evacuation alternatives have not yet received scholarly attention in Canada. This study focused on the community of Mt. Lorne, Yukon, and explored residents' perceptions of alternatives to evacuation due to wildfires, their evacuation intentions, and factors that influenced their intentions. Focus group participants planned to stay on their property despite a wildfire evacuation order because of the perceived safety of their property, and concerns about evacuating including leaving their property unprotected, losing harvested meat or other food stocks due to spoiling, and not knowing what to do with sled dog teams or livestock. However, some of these residents lacked the knowledge about how to stay on their property safely.
\end{abstract}

Keywords: wildfire, evacuation, evacuation alternatives, evacuation intentions, wildfire safety, Yukon, Canada

\section{RÉSUMÉ}

Les évacuations provoquées par les feux de forêt perturbent la vie des gens, ajoutent des risques additionnels aux équipes d'urgences et aux résidents et leurs exécutions sont dispendieuses. Des alternatives à lévacuation sont utilisées en Australie et par quelques juridictions aux États-Unis. Plusieurs études ont exploré loption « rester et lutter » au cours d'un feu de forêt en Australie et des alternatives à lévacuation ont également été étudiées aux États-Unis. Toutefois, les alternatives à lévacuation nont pas encore fait lobjet de recherche au Canada. La communauté de Mt Lorne au Yukon a été au centre de la présente étude qui a exploré les perceptions des résidents face aux alternatives à lévacuation à cause de feu de forêt, leurs intentions dévacuer et les facteurs qui ont motivé leurs intentions. Les participants du groupe de discussions avaient planifié de demeurer sur place malgré lordre dévacuation à cause d'un feu de forêt parce que la sécurité associée à leur propriété et les inquiétudes reliées à lévacuation pouvaient signifier de laisser leur propriété sans protection, de perdre leurs réserves de viande de chasse ou d’autres stocks de nourriture et de ne pas savoir quoi faire avec leurs chiens de traineau ou leurs animaux de ferme. Cependant, certains résidents navaient pas les connaissances requises pour rester en sécurité sur place.

Mots clés : feu de forêt, évacuation, alternatives à lévacuation, intention dévacuation, sécurité entourant les feux de forêt, Yukon, Canada

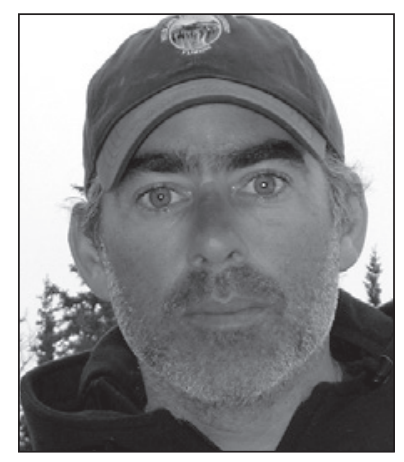

Doug W. Cote

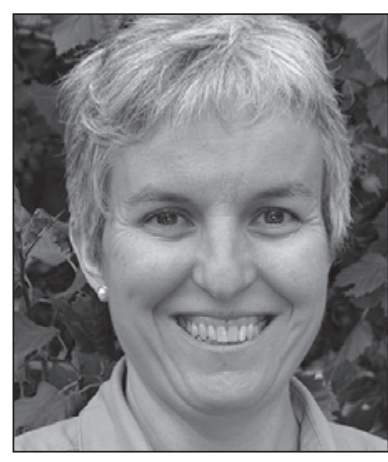

Tara K. McGee

\section{Introduction}

The aim of this study was to explore Canadian residents' perceptions of alternatives to evacuation, evacuation intentions and factors influencing intentions, using the small case study of the hamlet of Mt. Lorne, Yukon. The objectives were to:

1. Explore residents' perceptions of alternatives to evacuation during a wildfire;

2. Explore how residents planned to respond in the event of a wildfire in their area, and

3. Identify factors that may influence their intentions.

\section{Literature Review}

In North America, evacuations have and continue to be used as the main way to protect lives in the event of a wildfire (Haynes et al. 2008). All fire management agencies in Canada recommend evacuations in the event of a wildfire (Beverly and Bothwell 2011). Partners in Protection, a coalition of fire management

\footnotetext{
${ }^{1}$ Yukon Wildland Fire Management, Southern Lakes Region, Whitehorse, Yukon. E-mail: Doug.Cote@gov.yk.ca

${ }^{2}$ Department of Earth and Atmospheric Sciences, 1-26 Earth Sciences Building, University of Alberta, Edmonton, Alberta T6G 2E3.

${ }^{*}$ Corresponding author. E-mail: tmcgee@ualberta.ca
} 
agencies and fire management stakeholders in Canada raised the possibility of alternatives to evacuation in the first edition of their FireSmart guide (Partners in Protection 1999), but in the second edition the only option is to prepare for an evacuation (Partners in Protection 2003). In the United States, evacuation also remains the preferred policy, with the exception of a few communities where a shelter-in-place model has been adopted that focuses on individuals, families and communities being prepared to take shelter during a wildfire (Paveglio and Carroll 2007). In Australia, residents have been encouraged to prepare their properties and make a plan to leave early on a day of high fire risk or prepare to stay on their property in order to "defend" it during a bushfire (Coates et al. 2008). Since the 2009 Victorian bushfires, the recommended approach in the State of Victoria, Australia has changed to focus on leaving early and having evacuation options available in local communities. Residents are still given the option to stay and defend if certain conditions are met, such as having a bushfire safety plan in place (Victorian Bushfires Royal Commission 2010).

Researchers in Australia have examined the prepare, stay and defend or leave early options (Handmer and Tibbits 2005, Whittaker and Tibbits 2007, Stephens et al. 2009, Haynes et al. 2010). In the United States, where state policy focuses on evacuation in the event of a wildfire, researchers have examined the potential use of alternatives to evacuation (Paveglio et al. 2008, McCaffrey and Rhodes 2009). Implementation of sheltering in place as an alternative to evacuation by two communities in New Mexico has also been documented (Paveglio et al. 2008, 2010). More recently, researchers have examined the potential implications of policy changes after the Victoria 2009 wildfires in Australia and the U.S. (Paveglio et al. 2012). In Canada, where evacuations remain the policy and practice across the country, it is not clear how residents and emergency officials perceive alternatives to evacuation.

Researchers in the U.S. have also examined whether people are likely to evacuate or stay on their property during a wildfire. Mozumder et al. (2008) found that $89 \%$ of survey respondents in New Mexico stated that they would evacuate if ordered to do so under a mandatory evacuation order. Similarly, McCaffrey and Winter (2010) found that 11\% of survey respondents in California, Florida and Montana said they would stay on their property if there was a wildfire in their area. The potential evacuation or non-evacuation behaviour of Canadians remains unknown.

Existing hazard evacuation studies have identified a range of factors that affect residents' evacuation and non-evacuation (shelter-in-place or stay-and-defend) decision-making. The severity of a hazard event (Dow and Cuttter 2000, 2002; Whitehead et al. 2000; Zhang et al. 2007; Smith and McCarty 2009; Brommer and Senkbeil 2010; Petrolia et al. 2011) influences evacuation rates for hurricanes. Environmental and social cues have also been found to encourage evacuation (Mileti and Peek 2000, Stein et al. 2010). Warnings also influence hazard response (Drabek and Stephenson 1971, Perry 1979, Mileti and Peek 2000, Hasan et al. 2011). Household characteristics, such as type of residence (Whitehead et al. 2000, Smith and McCarty 2009, Hasan et al. 2011), location of family members (Perry 1979), perceived safety of the home, presence of children and elderly, and pet or livestock ownership (Dow and Cutter 2000, Whitehead et al. 2000) also influence evacuation decisions (Dash and Gladwin 2007). Travel costs (Dow and Cutter 2002, Elder et al. 2007), transportation availability (Elder et al. 2007), traffic concerns (Dow and Cutter 2002), a desire to protect valuables (Elder et al. 2007), and time away from other commitments (Lane et al. 2003) have also been found to affect evacuation decisions. This study will explore which factors influenced respondents' wildfire evacuation intentions in Mt. Lorne, Yukon.

\section{Methods and Materials \\ Study area}

This research was completed in the Hamlet of Mount Lorne, located $37 \mathrm{~km}$ south of Whitehorse, Yukon Territory, Canada. Mt. Lorne is 245 square kilometres in size, has a population of 410 , and includes 187 private dwellings. There is a very low density of properties and infrastructure, with an average property size of $6 \mathrm{ha}$, interspersed with larger agricultural parcels and large forested areas zoned as protected open space or hinterland. This community is located in a high-hazard area in terms of potential impacts from wildfire, due to its location among highly flammable forested stands of mature pine and spruce mix interspersed with small pockets of deciduous stands.

\section{Survey and focus group discussions}

In order to address the research, three focus group discussions were held in Mt. Lorne with a total of 12 participating local residents. Participants first completed a survey then participated in a focus group discussion. Participants were recruited via posters on community notice boards and mailbox clusters and via a public e-mail list of Mt. Lorne community members. These focus groups were held within a small community; therefore, many participants knew each other. The focus group discussions were two to three hours long and were held on four evenings during January 2011 at a local community centre. Of the 12 participants, three were female and nine were male, ranging in ages from 28 to 64 years old. The focus group discussions were conducted by the first author.

At the beginning of the focus group discussions, the first author provided an introduction to the study, a consent form, and a survey that included questions about residents' concern about a wildfire affecting their community, mitigation measures that they have completed on their property, their intention to evacuate or stay on their property in the event of a wildfire, and their awareness of the stay and defend option in Australia. This survey enabled us to identify residents' individual perspectives before the start of the focus group discussion. At the end of the focus group discussion, these questionnaires were collected for analysis. Once the questionnaire was completed by focus group participants, the first author gave a half-hour presentation to provide information about fire risks in the area, current fuel management activities being carried out by the Yukon Government in coordination with community associations, and recommended mitigation measures that can be carried out by residents on their own property. In addition, the Australian "stay and defend" evacuation alternative was explained and a fire growth model scenario based on actual fire behaviour and spread rates under normal weather conditions and fuel types in the valley that surrounds Mt. Lorne was shown. This background information stimulated subsequent discussion by focus group participants. During the focus group discussion, the first author facilitated discussion about participants' survey answers and about participants' preference to evacuate or stay and defend during a wildfire. A voice recorder combined with hand 
written notes were used to record the focus group discussions. Once the focus groups and interviews were complete, they were transcribed. The transcribed interview and focus group data and the surveys were then coded to identify key themes in the data.

\section{Results}

In the focus group survey, all except one participant stated that they had heard of stay and defend as an alternative to evacuation. When asked in the survey if they would prefer to evacuate or stay and defend in the event of a nearby wildfire, all 12 focus group participants indicated that they would prefer to stay and defend. In the words of one focus group participant during the subsequent discussion, "You would hate to leave, or be told to leave, and then come back and see everything burnt down because an ember landed on your lawn chair." During the focus group discussion, four participants said that they had always planned to stay and defend their property during a wildfire. Two of these four participants were firefighters.

The focus group discussion shed light on factors influencing participants' evacuation intentions. The perceived safety of participants' properties appeared to influence their evacuation intentions. As one focus group participant expressed, "I've got a huge irrigated field to the south and west, unlimited water out of Cowley Creek, hoses, nozzles... Of course I'm staying!” Ten of the 12 focus group participants indicated on their survey that they had completed actions on their property to help mitigate the wildfire risk. All reported that they had reduced forest fuels around their property by falling and removing limbs from trees and by hauling, chipping or burning flammable debris. Most participants stated that they had cleared all trees within 10 metres of their home and thinned stands up to 30 metres out from their structures. Nine participants indicated that they had a tin roof on their house, closed eaves, and/or sheathed in porches and decks. Four of these participants had also built their home with non-flammable siding such as stucco or cement board and had tempered heat-resistant windows.

During the focus group discussions, participants expressed several concerns about evacuating, which influenced their desire to stay on their property during a wildfire. The prospect of leaving their property unprotected from fire if forced to evacuate was discussed by participants in all three focus groups. Participants also raised the concern that if required to evacuate they might lose harvested meat or other food stocks due to spoiling. Another concern raised by participants was about what to do with sled dog teams or livestock if they were forced to evacuate. Two participants with dog teams did not know how they would evacuate and indicated that they "had never really considered" an evacuation plan for their dogs or themselves. All participants have friends or neighbours with dog teams, so this concern was also raised by other participants. All participants also expressed concerns about being evacuated to Whitehorse because a fire affecting Mount Lorne would result in smoke impacts in Whitehorse. These concerns about evacuating likely contributed to participants' desire to stay on their property during a wildfire.

Although all participants stated that they planned to stay on their property instead of evacuating during a wildfire, during the focus group discussion it was apparent that participants were only confident in their mitigation and preparedness efforts as well as their ability to stay and defend their property "up to a point". One participant described this point as being when the fire got too close to the homes and was "too large". Eight of the twelve participants agreed with this statement, and one added that it would be "when they began to feel really uncomfortable" from the heat and stress. Focus group participants considered that conditions would be "too bad" if the fire was "consuming the entire valley", or was approaching from the North (because the prevailing winds are from the South the majority of participants had completed little mitigation on the north side of their home). Therefore the severity of a wildfire clearly influenced participants' intentions. In the focus groups, a majority of participants expressed that they might also consider trying to flee from their property if conditions became extreme. This is a concern because fleeing at the last minute during a wildfire is considered one of the most dangerous actions (Haynes et al. 2008, Cova et al. 2009, Stephens et al. 2009, Beatson and McLennan 2011). Further discussion in the focus group revealed that some participants may not be able to identify an extreme fire, as noted in the words of one participant: "There may be a clump of 20 trees going up in front of my house and I may think the whole valley is on fire." Having limited or no direct experience with large fires and limited or no wildfire training, participants were unsure about what they would experience if they followed through on their intentions to stay and defend their property during a wildfire.

During the focus group discussions, more than half of the participants reported that although they planned to stay on their property during a wildfire, they did not feel comfortable sheltering in their home while the fire front passed through their property. This discomfort was apparent in the words of one participant: "Is it going to hurt? I don't know how dangerous it is when a fire roars through your property. Is it possible to go into the crawl space for an hour and come back with a little pump and a sprayer?" In addition, all focus group participants expressed that sheltering in the home seemed almost alarming and counter-intuitive as a strategy for survival during a wildfire. One focus group participant expressed concern that his wooden house might ignite due to ember transport, and he was more comfortable with sheltering in the openness of his field. Another said that being "down at the creek" would be safer because the house had "some vulnerabilities" in terms of defensible space and home construction. These participants did not appear to understand the importance of sheltering from radiant heat during a wildfire (Cohen 1995, Alexander et al. 2012). The uncertainties and concerns that participants expressed about staying on their property during a wildfire led to discussion about the need for more information and training so that they could stay safely on their property. As one of the focus group participants expressed, "Jeez, if you're out there and your place gets engulfed, what do you do? You know? I have those kinds of questions. I would like to get some training in that."

\section{Discussion}

Throughout Canada, evacuation is the only option supported by governments to protect residents in the event of a wildfire. In the Yukon, alternatives to evacuation are not supported because they are beyond the scope of the agency's current mandate and would be difficult to develop and implement given Yukon Wildland Fire Management's capacity and resource levels. However, the results of this study show that some residents in the Yukon Territory appear to understand their local wildfire risks, have 
implemented mitigation and preparedness measures to help protect their home in the event of a wildfire, and intend to stay and defend their property in the event of a wildfire despite concerns and a lack of knowledge about how to do so safely. Some others were less knowledgeable and yet still intended to stay and defend their property. These findings suggest a need for more communication between wildfire management agencies and local residents to ensure that residents understand local wildfire risks and those who plan to stay behind are well informed, knowledgeable, and adequately prepared. The very small sample size in this study should be supplemented by further research to identify to what extent residents living in Canadian communities in the North and elsewhere in the country are intending to stay on their property during a future wildfire. Research completed in the US indicates that $11 \%$ of residents in California, Florida and Montana plan to stay on their property during a future wildfire evacuation (McCaffrey and Winter 2010, Mutch et al. 2011). Further study is needed to obtain an understanding of Canadians' wildfire evacuation intentions, and to identify factors that influence evacuation intentions.

Participants' reasons for staying behind included perceptions that their property will be safe in a wildfire, and concerns about leaving their house unprotected, loss of harvested meat or other food, and sled dog teams or livestock. Other researchers have also found that owning livestock can make residents reluctant to evacuate during wildfires (Mozumder et al. 2008) and other hazards (Dash and Gladwin 2007). These findings indicate a need to provide evacuation support in remote Northern communities to reduce the loss of harvested meat, and in this community to look after sled dog teams and livestock.

\section{Acknowledgements}

We would like to thank the residents of Mt. Lorne who participated in focus group discussions. Douglas Cote also thanks his colleagues at Yukon Wildland Fire Management for formal discussions in the office to the less formal chats on riverbanks, ridge tops, or in helicopters - their perspectives and insights are truly appreciated.

\section{References}

Alexander, M.E, R.W. Mutch, K.M. Davis and C.M. Bucks. 2012. Wildland fires: Dangers and survival. In P.S. Auerbach (ed.). Wilderness Medicine. $6^{\text {th }}$ ed. pp. 240-280. Elsevier, Philadelphia, PA.

Beatson R. and J. McLennan. 2011. What applied social psychology theories might contribute to community bushfire safety research after Victoria's “Black Saturday”. Australian Psychologist 46(3): 171-182.

Beverly, J.L. and P. Bothwell. 2011. Wildfire evacuations in Canada 1980-2007. Natural Hazards 59(1): 571-596.

Brommer, D.M. and J.C. Senkbeil. 2010. Pre-landfall evacuee perception of the meteorological hazards associated with Hurricane Gustav. Natural Hazards 55(2): 353-369.

Coates, L., G. Ganewatta, J. Handmer, K. Haynes, J. McAnaney and A. Tibbits. 2008. 100 years of Australian civilian bushfire fatalities: exploring the trends in relation to the "stay and go policy". Report for Brushfire CRC.

Cohen, J. 1995. Structure ignition assessment model (SIAM). In D.R. Weise and E. Robert (eds.). Proceedings from the Biswell Symposium: Fire Issues and Solutions in Urban Interface and Wildland Ecosystems. pp. 85-93. United States Department of Agriculture Forest Service, Walnut Creek, CA. Gen. Tech. Rep.

Cova, T.J., F.A. Drews, L.K. Siebeneck and A. Musters. 2009. Protective Actions in Wildfires: Evacuate or Shelter-in-Place? Natural Hazards Review 10(4): 151-162.
Dash, N. and H. Gladwin. 2007. Evacuation decision making and behavioural responses: Individual and household. Natural Hazards Review 8(3): 69-77.

Dow, K and S.L. Cutter.2000. Public orders and personal opinions: household strategies for hurricane risk assessment. Global Environmental Change Part B: Environmental Hazards 2(4): 143-155.

Dow, K. and S.L. Cutter. 2002. Emerging hurricane evacuation issues: Hurricane Floyd and South Carolina. Natural Hazards Review 3(1): 12-18.

Drabek, T.E. and J.S. Stephenson. 1971. When Disaster Strikes. Journal of Applied Social Psychology 1(2): 187-203.

Elder, K., S. Xirasagar, N. Miller, S.A. Bowen, S. Glover and C. Piper. 2007. African Americans' decisions not to evacuate New Orleans before Hurricane Katrina: A Qualitative Study. American Journal of Public Health 97(S1): 124-129.

Handmer, J. and A. Tibbits. 2005. Is staying at home the safest option during bushfires? Historical evidence for an Australian approach. Environmental Hazards: Human and Policy Dimensions 6(2): 81-91.

Hasan, S, S. Okkusuri, H. Gladwin and P. Murray-Tuite. 2011. Behavioral model to understand household-level hurricane evacuation decision making. Journal of Transportation Engineering 137(5): 341-348.

Haynes, K., J. Handmer, J. McAneney, A. Tibbits and L. Coates. 2010. Australian bushfire fatalities 1900-2008: exploring trends in relation to the "Prepare, stay and defend or leave early" policy. Environmental Science \& Policy 13(3): 185-194.

Haynes, K., A. Tibbits,, L. Coates, G. Ganewatta, J. Handmer and J. McAneney.2008. 100 years of Australian civilian bushfire fatalities: Exploring the trends in relation to the "prepare, stay and defend, or leave early policy". Journal of Environmental Science and Policy 13(3): $122-154$

Lane, L.R., G.A. Tobin and L.M. Whiteford. 2003. Volcanic hazard or economic destitution: Hard choices in Banos, Ecuador. Global Environmental Change Part B: Environmental Hazards 5(1-2): 23-34.

McCaffrey, S. and A. Rhodes. 2009. Public response to wildfire: Is the Australian "stay and defend or leave early" approach an option for wildfire management in the United States? Journal of Forestry 107(1): 9-15.

McCaffrey, S.M. and G. Winter. 2010. Understanding homeowner preparation and intended actions when threatened by a wildfire. Proceedings of the Second Conference on the Human Dimensions of Wildland Fire. Available at http://www.nrs.fs.fed.us/pubs/gtr/gtr-nrs-p84papers/12mccaffrey-p-84.pdf.

Mileti, D.S. and L. Peek 2000. The social psychology of public response to warnings of a nuclear power plant accident. Journal of Hazardous Materials 75(2000): 181-194.

Mozumder, P., N. Raheem, J. Talberth and R.P. Berrens. 2008. Investigating intended evacuation from wildfires in the wildland-urban interface: application of a bivariate probit model. Forest Policy and Economics 10(6): 415-423.

Mutch, R.W., M.J. Rogers, S.L. Stephens and A.M. Gill. 2011. Protecting lives and property in the wildland-urban interface: communities in Montana and Southern California adopt Australian paradigm. Fire Technology 47: 357-377.

Partners in Protection. 1999. Firesmart: Protecting Your Community from Wildfire. First Edition.

Partners in Protection. 2003. Firesmart: Protecting Your Community from Wildfire. Second Edition.

Paveglio, T.B., A.D. Boyd and M.S. Carroll. 2012. Wildfire evacuation and its alternatives in a post-Black Saturday landscape: Catchy slogans and cautionary tales. Environmental Hazards 11(1): 52-70.

Paveglio, T. and M. Carroll.2007. Advancing the discussion of shelterin-place as a means of protecting public safety during wildland fire. Retrieved from network.firewise.org

Paveglio, T.B., M. Carroll and P.J. Jakes. 2008. Alternatives to evacuation: Protecting public safety during wildland fire. Journal of Forestry 106(2): 65-70. 
Paveglio, T.B., M. Carroll and P.J. Jakes. 2010. Adoption and perceptions of shelter-in-place in Californias Rancho Santa Fe Fire Protection District. International Journal of Wildland Fire 19: 677-688.

Perry, R.W. 1979. Evacuation decision-making in natural disasters. Mass Emergencies 4: 25-38.

Petrolia, D.R., S. Bhattacharjee and T.R. Hanson. 2011. Heterogeneous evacuation responses to storm forecast attributes. Natural Hazards Review 23(3): 117-124.

Smith, S.K. and C. McCarty. 2009. Fleeing the storm(s): An examination of evacuation behavior during Florida's 2004 hurricane season. Demography 46(1): 127-145.

Stephens, S. L., M.A. Adams, J. Handmer, F.R. Kearns, B. Leicester, J. Leonard and M.A. Moritz. 2009. Urban-wildland fires: How California and other regions of the US can learn from Australia. Environmental Research Letters 4(1): 1-5.

Stein, R.M., L. Duenas-Osorio and D. Subramanian. 2010. Who evacuates when hurricanes approach? The role of risk information and location. Social Science Quarterly 91(3): 816-834.
Victorian Bushfires Royal Commission. 2010. Final report recommendations. Available at http://www.royalcommission.vic.gov.au/ Commission-Reports.

Whitehead, J.C., B. Edwards, M. Van Willigen, J.R. Maiolo, K. Wilson and K.T. Smith. 2000. Heading for higher ground: factors affecting real and hypothetical hurricane evacuation behavior. Global Environmental Change Part B: Environmental Hazards 2(4): 133-142. Whittaker, J. and A. Tibbits. 2007. Stay and defend or leave early: Policy problems and experiences during the 2003 Victorian bushfires. Environmental Hazards: Human and Policy Dimensions 7(4): 283-290.

Zhang, F., R.E. Morss, J.A. Sippel, T.K. Beckman, N.C. Clements and N.L. Hampshire. 2007. An in-person survey investigating public perceptions and responses to Hurricane Rita forecasts along the Texas coast. Weather and Forecasting 22(6): 1177-1190. 